\title{
DETERMINING FACTORS OF DEPOSIT LEVEL OF ISLAMIC BANK IN INDONESIA
}

\author{
Sofyan Baehaqie ${ }^{1}$, Idqan Fahmi², Irfan Syauqi Beik ${ }^{3}$
}

\begin{abstract}
Determining Factors of Deposit Level of Islamic Bank In Indonesia. One Way to maintain the stability of banking industry is by applying the deposit insurance scheme. The application of the deposit insurance scheme has an impact by increasing the level of bank deposits. The objectives of the research are to identify the factors affecting the level of deposits of Islamic banks in Indonesia and managerial implications regarding to the functions of Indonesia Deposit Insurance Corporation (LPS). The technique used is the panel data regression with fixed effect model using the data from the 11 Islamic banks for the period of $2011-2015$. The results show that the factors affecting the level of deposits of the Islamic banks in Indonesia significantly and positively include the size of banks and their non-performing financing (NPF); however, they influence the capital negatively. Based on these results, LPS is required to build or sharpen the surveillance systems as part of its early detection by doing the mapping based on the size and to monitor the bank capital structure and bank finance portfolio structure.
\end{abstract}

Keywords: Islamic bank, deposit level, panel regression.

\begin{abstract}
Abstrak. Determinan yang Memengaruhi Tingkat Deposit Bank Umum Syariah di Indonesia. Salah satu cara untuk menjaga stabilitas industri perbankan adalab dengan menerapkan skema penjaminan simpanan. Penerapan skema penjaminan simpanan dapat meningkatkan tingkeat deposit bank. Tujuan penelitian ini adalab untuk mengetahui faktor-faktor yang memengarubi tingkat deposit bank. umum syariah di Indonesia dan implikasi manajerial berkenaan fungsi penjaminan Lembaga Penjamin Simpanan (LPS). Tehnik yang digunakan adalah regresi data panel dengan metode fixed effect model dan menggunakan data 11 bank umum syariah pada periode 2011 -2015. Hasil penelitian menunjukean bahwa faktor yang memengarubi tingkat deposit bank umum syariah di Indonesia secara signifikan dan positif adalah ukuran bank. dan non performing financing (NPF), sedangkan permodalan berpengaruh secara negatif. Berdasarkan hasil tersebut, LPS perlu membangun atau mempertajam sistem pengawasan sebagai bagian dari early detection dengan melakukan mapping berdasarkan ukuran dan, melakukan pemantauan terbadap struk.tur permodalan bank dan struktur penyaluran pembiayaan bank.
\end{abstract}

Kata kunci: bank umum syariah, tingkat deposit, regresi data panel. 


\section{Introduction}

In 2015, the market share of the banking sector reached $78.62 \%$ from total financial asset or equivalent to IDR 6.021 trillion of IDR7.658 trillion financial asset. With the huge of asset share of banking industry, Goverment needs to keep the stability within the vast expansion in the banking industry. Kunt and Kane (2002) explain about some policies to stabilize the banking system, such as the prudential surveillance banking system, the deposit insurance function, and the function of the central bank as the lender of the last resort. Anginer et al. (2014) stated that the deposit insurance scheme had a stabilizing effect during the crisis period even though not in normal times.

Indonesia has already applied the deposit guarantee scheme during economic crisis in 1998. The guarantee program was continued by esthablishing a special agency through Law Number 24 in 2004 concerning Lembaga Penjamin Simpanan (LPS) or Indonesia Deposit Insurance Corporation (IDIC). The implementation of the deposit insurance scheme has successfully increased the public trust to the banking industry. It is shown by the rise in the deposit from the banking sector as can be seen in Figure 1, and this is inline with the research of Chernykh and Cole (2011) regarding implementing effect of deposit insurance scheme in Russia.

Figure 1. The performance development in banking 2001-2015

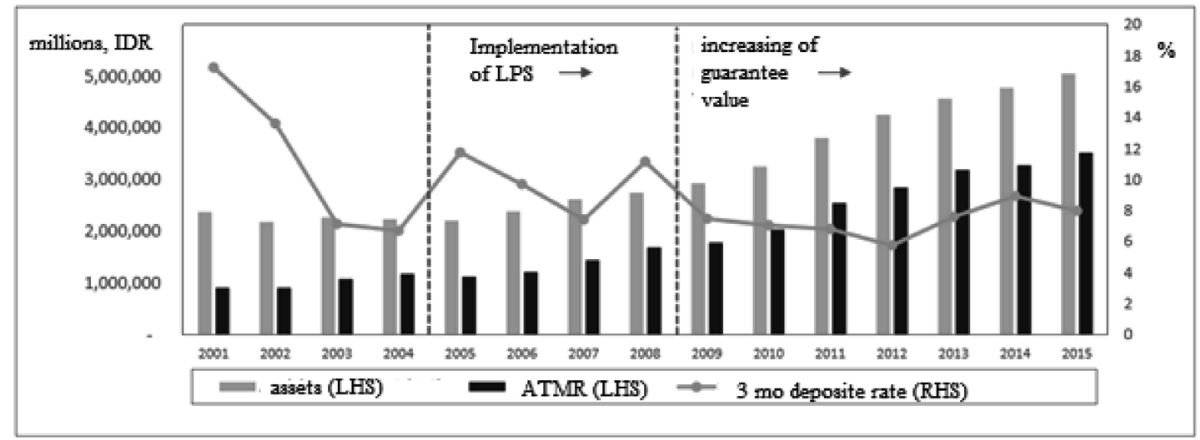

Source: OJK - Finansial Report (2001-2015)

In last 5 years, the Islamic banking industry has a positive growth (Figure 2). Alamsyah (2012) reported some factors that support the growth of Islamic banks. Those factors are: First, expansion of Islamic branch network. Second, Islamic banking education program on Islamic products. Third, improvement in Islamic banking services (service excellent). Fourth, ratification of some legislations 
to provide the legal certainty to support Islamic market activities such as Law No.21 2008 concerning Islamic Banking and Law No.19 2008 concerning Islamic Obligation (Sukuk). The implementation of the new law increases the number of Islamic banks from 5 to 11 in only 2 years (2009-2011). Fahmi (2012) indicates that the Islamic banking is a complementary in the banking industry. Thus, the growth in the conventional banking will lead to the development of the Islamic banking; furthermore, the conventional banking is not a substitution or a threat for the Islamic banking. Solihin (2015) emphasized the importance of the readiness of Indonesian Islamic banks in facing the ASEAN free market. Islamic banks in Indonesia should reduce the operational costs so it can be more efficient and grow well. The development of Islamic banking industry in industry after the spin-off policy is so rapid, although according to Al Arif (2015) the spin-off affect the efficiency declining.

Figure 2. The Trend of Islamic banking growth

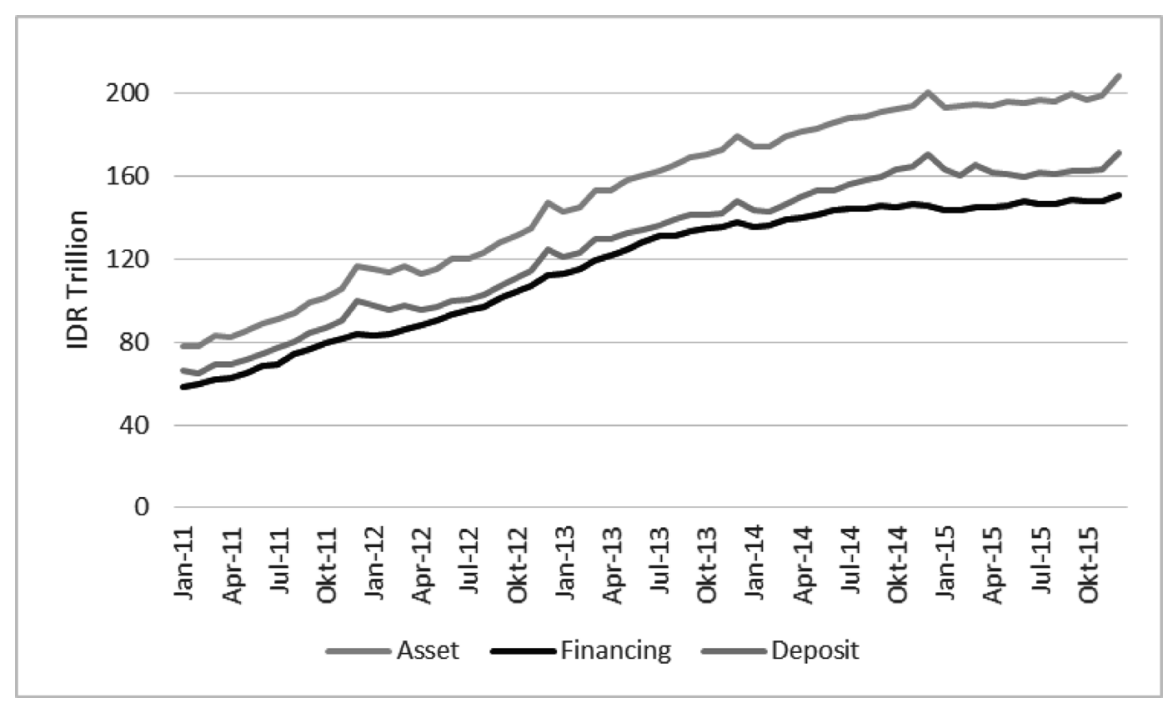

Source: OJK \& LPS - Bank monthly report (2016)

Although there is rapid growth in the Islamic banking, LPS has not separated the Islamic deposit insurance with the conventional banking insurance yet. One of the reasons is the market share of the Islamic banking is not significant compared to that of the national banking industry i.e. only 4.79\% (OJK Quarter I Report, 2016). Still, IDIC has the intension to insure the Islamic deposit. It is show LPS role to maintain the stability and sustain growth of Islamic banks through fundraising and 
it will help Islamic banking grow and become an important player in the banking sector in Indonesia.

As mention above, it can be concluded that this research is useful for LPS to develop the monitoring system of Islamic banks in order to maintain banking system stability. In addition, this research also can be useful for banks to develop strategies to improve fundraising capabilities. This research will examine the characteristics and affecting factors of deposit level of Islamic Banks in Indonesia and managerial implications both for LPS as well as for banks regarding LPS function to maintain the banking system stability and strategies in collecting funds for banks.

\section{Literatur Review}

The basis of Islamic banking as a financial institution has been known by Islam based on consepts in the holy Al-Quran while the form and the mechanism of the organisation are managed by the moslems (Muhamad, 2012; Karim, 2006). The concepts that are derived from the Al-Quran such as accountability are derived from Al-Baqarah 282-283, trust and justice are from Al-An'am 70 and An-Nisa 3, usury concept is from Al-Baqarah 275 and 278-279. The practices of those concepts have already been known since Muhammad reign (Karim, 2006). A few examples include the Makkah community that trusted their treasure to Muhammad (wadi'ah concept) and Zubair bin Awwam that prefered to receive the treasure in the form of loan (mudharabah concept).

Currently, the function of the bank is highly developed. According to Budisantoso and Nuritomo (2014), the bank functions as an agent of trust where people can save their money and the bank will distribute it back (intermediary). The bank also functions as the agent of development which supports the development and as the agent of services to provide the financial services. King and Levine (1993) suggest that the bank's intermediary function is an important factor in the economy of a country. Ho and Saunders (1981) said that a bank is the dealer in the credit market due to its function as the intermediation between the demanders of funds and suppliers of funds. Siringoringo (2012) finds that the intermediary function of the Indonesian banks is influenced by the ownership structure: government, domestics, foreign; profitability; size; credit risk; expense management, and the capital structure is simultaneously influential on the bank intermediary function. Arshad (2011) argues that Islamic insurance is applied to avoid the probability of loss from the failure of the Islamic banks. The Islamic deposit insurance can be implemented although it is not regulated in Muhammad authority because it is related with public interest (maslahah) when it meets the sharia regulations such as: being free 
from interest rate (riba), free from uncertainty (gharar), and free from gambling (maisir). Muhammad and Lestari (2015) emphasized the importance of guarantee for Islamic banking by basing on the contract specified in Islamic jurisprudence rules. Based on the International Association of Deposit Insurer (2010), "Islamic deposit insurance is an arrangement to protect insured depositors against the loss of their insured Islamic deposits placed with Islamic banking institutions (IBIs) in the event of an IBI's failure. In this regard, the system must be free from the elements that Islam strictly prohibits, such as interest, speculation, and gambling". Kafalah bil ujr and takaful is main contracts that can be used in Islamic insurance scheme (CIBEST IPB, 2014).

Chernykh and Cole (2011) find that bank membership in the deposit insurance system influences the ability of the bank to collect funds (deposits). The other factor that has an effect to deposit insurance is capital; the increase in the capital will reduce the credit risk; therefore, it will raise the public trust to save their money in banks (Vale, 2011). Tsuru (2003) finds that there is a negative correlation between non performing financing and deposit amount. Nuryantono et.al. (2016) found that there are only 3 of the 9 sectors that have non performing financing ratios below average i.e. electricity, water and gas, as well as business services and social service sector. Lusian et al. (2015) sees that unoptimal collection of deposits as a source of increased non performing financing. The capability of the bank to collect deposit is very crucial for its intermediary function. Siringoringo (2012) shows that the ownership structure, profitability, size and the capital structure have consequences to the banking intermediation function in Indonesia.

Rokhim and Wulandary (2012) with their panel data regression found that the implementation of the deposit guarantee does not affect the level of commercial bank deposits in Indonesia. On the contrary, the existence of deposit insurance increases the risk of moral hazard of the commercial banks. BI regulations related to loan capital adequacy ratio and non-performing are proven to be effective in minimizing the risk of moral hazard of the commercial banks in Indonesia; however, the capital adequacy ratio is not shown to affect the level of commercial bank deposits. Meanwhile, high non-performing loans are proven to affect the amount of funds raised from the public by commercial banks in Indonesia. Another conclusion from this study is the implementation of deposit insurance and capital adequacy ratio is not shown to affect a significant NIM variables; on the other hand, NPL variables negatively affect NIM. Nasution (2012) using panel data regression model and descriptive analysis found that the guarantee program is proven to be effective in increasing the deposits of commercial banks and lowering the concentration of deposits in state-owned banks (SOE). In addition, the implementation of the 
deposit guarantee is not shown to increase risk-taking in the form of a decrease in the composition of capital to assets or an increase in credit to the bank's asset composition.

Widigdo et.al. (2016) in their study on business process engineering of funding in Islamic banking in Indonesia emphasized the need to remodel business process of collecting deposits through increasing the accessibility of prospective depositors and increasing the accessibility of existing in order to encourage saving habit. Wiranatakusuma and Duasa (2017) in their research related to the resistance of Islamic banking on external factors found that deposits and financing have been standardized, thus describing its resistance. Additionally, some macroeconomic indicators such as $\mathrm{M} 2 /$ reserves, credit growth, real effective exchange rate, and inflation rates empirically become the key indicator of susceptibility signals.

\section{Method}

This research analysed the bank monthly reports of the 11 Islamic banks for the period of 2011-2015. The sources of the report come from OJK, BI, LPS, and/ or other Islamic Banking Institutions. The research was conducted from August 2016 to October 2016. It used panel data regression to analyze the data. The data set consisted of cross section and time series data (Greene, 2003). The cross section data are showed by the data consisting of more than one entity (individual) while the time series data are represented by any individual who has more than one period observation. The regression model tested in this research and the description of th variables will be as follows:

$$
\mathrm{YTKD}_{i, \mathrm{t}}=\alpha_{\mathrm{i}, \mathrm{t}}+\beta_{1} \operatorname{lnSIZ} \mathrm{i}_{\mathrm{i}, \mathrm{t}}+\beta_{2} \mathrm{CAR}_{\mathrm{i}, \mathrm{t}}+\beta_{3} \mathrm{NPF}_{\mathrm{i}, \mathrm{t}}+\beta_{4} \mathrm{INF}_{\mathrm{i}, \mathrm{t}}+\beta_{5} \mathrm{BIR}_{\mathrm{i}, \mathrm{t}}+\varepsilon
$$

Table 1 . The description of the variables

\begin{tabular}{lll}
\hline \multicolumn{1}{c}{ Variables } & \multicolumn{1}{c}{ Description } & \multicolumn{1}{c}{ Measurement } \\
\hline $\begin{array}{l}\text { The size of the bank } \\
\text { (SIZ) }\end{array}$ & $\begin{array}{l}\text { The size of the bank is seen from its individual total Natural logarithm } \\
\text { asset which shows its ability to perform the business. from Rp million } \\
\text { Capital (CAR) }\end{array}$ & $\begin{array}{l}\text { Capital is the financial capability of each individual Percentage } \\
\text { Islamic bank to absorb risks, including the financing } \\
\text { risk. The parameter of capital is Capital Adequacy }\end{array}$ \\
& $\begin{array}{l}\text { Ratio (CAR). } \\
\text { Non performing }\end{array}$ & $\begin{array}{l}\text { Non-performing financing reveals the risk of Islamic Percentage } \\
\text { financing by comparing between the non-performing } \\
\text { financing and total financing. }\end{array}$ \\
\hline
\end{tabular}




\begin{tabular}{ll}
\hline $\begin{array}{l}\text { Inflation (INF) } \\
\begin{array}{l}\text { Inflation is the condition where prices increase Percentage } \\
\text { continuously. The price consumer index is the common } \\
\text { indicator for this variable. }\end{array}\end{array}$ \\
$\begin{array}{l}\text { The changing in BI } \\
\text { rate (BIR) }\end{array}$ & $\begin{array}{l}\text { BI rate is the policy rate issued by BI. It indicates the Percentage } \\
\text { monetary policy. }\end{array}$ \\
Deposit level (TKD) & The comparison between the total deposit and the asset.
\end{tabular}

\section{Result and Discussion}

Deposit and financing can be used to determine the level of resilience of Islamic banking (Wiranatakusama and Duasa, 2017). The development of Islamic banks in the period of $2011-2015$ has generally a positive growth with compund annual growth rate of 3 (three) major components is $12.27 \%$ (assets), $12.51 \%$ (financing) and $11.45 \%$ (deposits). Nevertheless, in 2014 and 2015 as can be seen in Figure 3 and Table 2, financing on average fell significantly to $6.04 \%$ and $3.46 \%$ compared to $2012(34.41 \%)$ and $2013(22.26 \%)$ and experiencing slowing growth. This is partly due to the uncertainty in the economy and global financial markets caused by the slowing global economic recovery.

Table 2 . Yearly compound annual growth rate (\%)

\begin{tabular}{ccccc}
\hline & $\mathbf{2 0 1 2}$ & $\mathbf{2 0 1 3}$ & $\mathbf{2 0 1 4}$ & $\mathbf{2 0 1 5}$ \\
\hline Asset & 25.74 & 22.08 & 11.92 & 3.84 \\
Financing & 34.41 & 22.26 & 6.04 & 3.46 \\
Deposit & 24.81 & 18.89 & 15.56 & 0.27 \\
\hline
\end{tabular}

Source: OJK \& LPS - Bank monthly report, 2016

The objectives of this research is to study the growth of deposits in the bank by measuring the proportion of the deposit amount compared to total asset. The information on the deposit shows the ability of the bank to collect funds which at the end will be distributed to public by the bank as its function as an intermediary agent. Based on the observation period for 5 years (2011-2015), the growth of the deposits in Islamic banks was between 68.70\% (Februari 2011) and 79.91\% (April 2015). This represents the competence of the bank to collect fund when there is an increase in its asset. 
Figure 3. Growth of 3 (three) Main Indicator of Islamic Banks

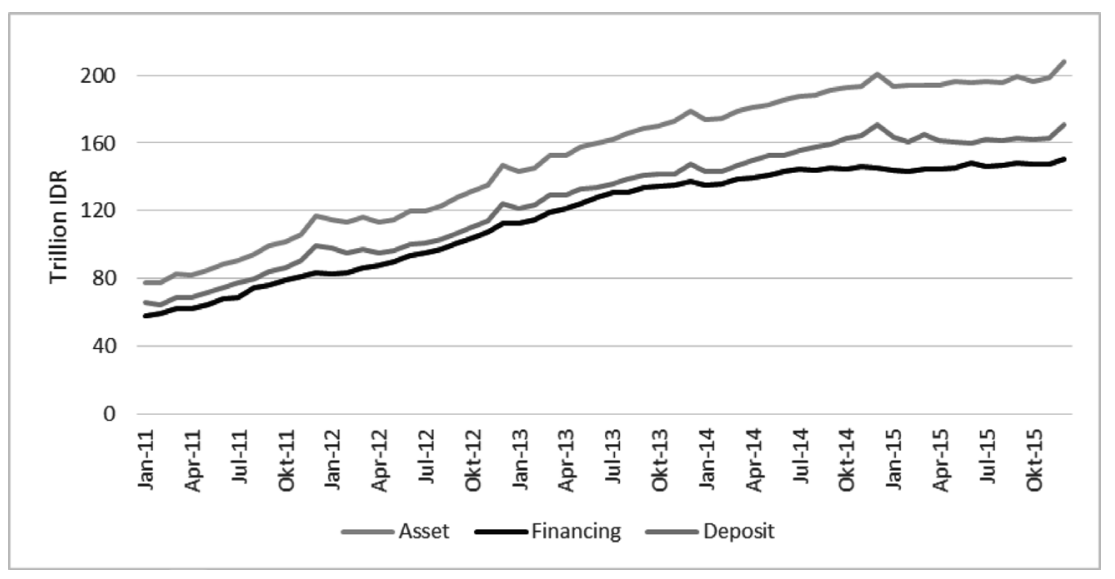

Source: OJK \& LPS - Bank monthly report, 2016

A bank has a good intermediary function if it has the ability to collect fund and distribute it for financing. The intermediary ability is measured by Financing to Deposit Ratio (FDR). Based on the data during the observation, the lowest average of FDR was 87.12\% in May 2011 and the highest was $121.87 \%$ in September 2012. In some period, the FDR of Islamic banks was fullfil the requirement level of FDR according to the Regulation of Bank Indonesia No. 15/16/PBI/2013 on Reserve Requirement in Rupiah and Foreign Currencies fo Islamic Banks. The high level of FDR shows that the funding function cannot balance the aggresive financing. The growth of the deposit level and FDR of Islamic banks can be seen in Figure 4.

Figure 4. The movement of the deposit level and FDR

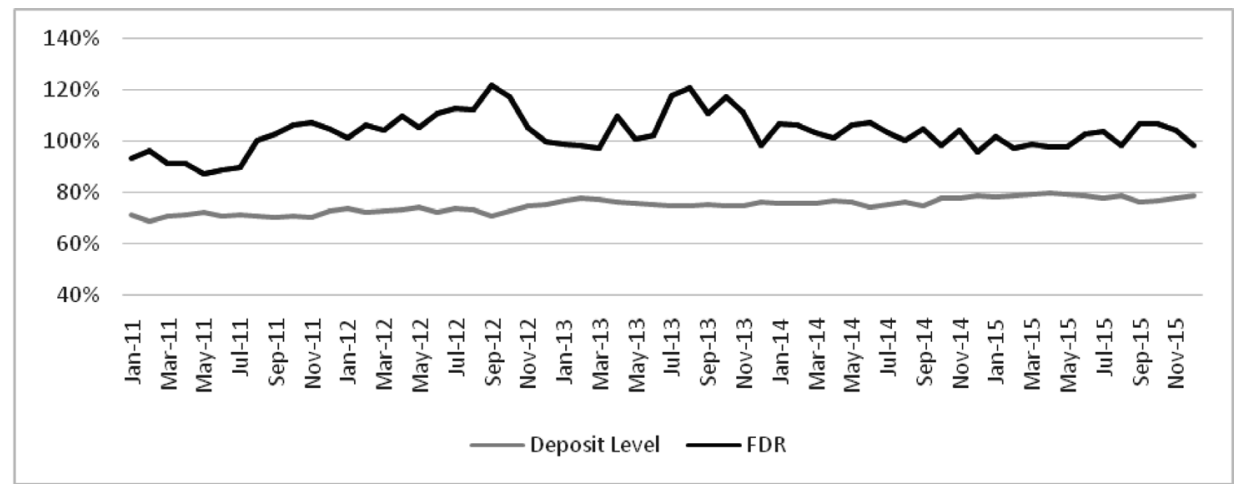

Source: OJK, Bank Monthly Report 2011-2015 
In individually sight, Bank $\mathrm{A}$ as one of the biggest bank in assets has a good capability in collecting fund with value of the deposit level at $86.9 \%$. This could be as the consequence of its massive office and branches. In 2015, it had 865 channels with 136 main branches, 469 support branches, 50 mortgage offices, 60 cash outlets, 145 payment points, and 5 service points. Mean while Bank $\mathrm{X}$ as one of the smallest bank in assets has the highest FDR rate with value of $205.55 \%$. The high level of FDR shows its inability to collect fund as represented by its low deposit level with only $33.6 \%$ which is due to lack of office and branches. Thus, this bank uses money market and its own capital for its funding source. This is inline with the research of Almejyseh and Rajha (2014) who considered that the amount of branches is one of the important parameters affecting customer deposits. Masamba et al. (2014) emphasized the importance of increasing the number of deposits by entering new markets through branch expansion, low-cost account products, and increase in returns on deposits.

Based on the classical assumption tests (Chow Test, Hausman Test, and Autocorrelation Test), Fixed Effect Model is the model that is applicable for this research. Table 3 presents the regression result according to this model.

Table 3. The regression result for the deposit level

\begin{tabular}{ccc}
\hline Variabel & Koefisien & Prob. \\
\hline LnSIZ & 0.026156 & 0.0296 \\
CAR & -0.321698 & 0.0000 \\
NPF & 0.238936 & 0.0076 \\
INF & 0.040935 & 0.6348 \\
BIR & -0.160043 & 0.6367 \\
AR(1) & 0.649399 & 0.0000 \\
AR(2) & 0.170794 & 0.0000 \\
R-squared & 0.952580 & \\
\hline
\end{tabular}

*Significant at $5 \%$

According to the regression result, the value of adjusted R-squared is 0.952580. It means that the independent variable of $95.25 \%$ can explain the level deposit and the rest is caused by the other variables outside the model. The variables that significantly influence the deposit level at 5\% significant level include bank 
assets, capital, and non-performing financing; however, inflation and BI rate are insignificant. The result also obtained a significant influence of the occurrence in the previous time or known as Autoregresive (AR) which is marked with AR (1) and AR (2). The autoregresive explains that the deposit lavel is affected by the values on factors occurring in the previous 2 (two) periods (in this case 2 months prior to January 2011).

Specifically, the variable of aset bank with score of 0.02615 is significantly influential. The value of the asset has been made in the natural logarithm so it presents that every $1 \%$ increase in aset will increase the level of deposit in $0.026 \%$. Based on data from bank reports, it is found that the average ability to raise funds for the 4 largest banks in asset ranges from $81.15 \%$ to $86.99 \%$. Meanwhile for the 4 banks with the smallest in asset are between $33.62 \%$ to $75.33 \%$. The variable of aset has become attractiveness factor for depositor to place their funds in well established Islamic banks rather the new one. This is explain the large gap between main Islamic banks with others. Banks with a big number in asset will have a large number of branches and it will impact on accessibility for depositor and much easier for the bank to collect the fund. This result is different from the research of Rokhim and Wulandary (2012).

CAR is the other variable that significantly influences the level of deposit variable in a negative way with score of 0.321698 . It presents that every $1 \%$ increase in CAR, the level of deposit will decrease by $0.32 \%$, this result is inline with Rokhim and Wulandary (2012). During the observation period, the CAR of Islamic banks is high since there are capital injection from shareholders as part of fulfillment of regulation related to minimum capital of Islamic bank. Based on data from bank reports, the highest on CAR ratios dominated by the smallest banks in asset with average ranging from $36.40 \%$ to $70.84 \%$. This is as a result from inability of the banks to disburse financing. It should provide security for depositor because banks have sufficient capital reserve to prevent banks from default. Nevertheless, additional capital from shareholders also gives a negative signal to depositors with increased control of shareholders who can lead banks to generate greater profits. This increases the risk of moral hazard which could be a negative signal for depositors to place funds in the banks.

NPF variable has a significant influence and positive correlation to the level of deposit with score of 0.238936 . Every $1 \%$ increase in NPF will increase the level of deposit by $0.23 \%$. The results obtained are not inline with Rokhim and Wulandary (2012), where a high NPF ratio should be a signal to customers that the bank has an inadequate prudential principle in its financing activities. There is a possibility that a positive correlation arises because the depositors 
has a strong believes that the bank is able to manage the NPF ratio and it shown by the average net NPF ratio of $1.50 \%$. In addition, depositors also recognize the additional capital injection by shareholders although it also raises shareholder influence on the bank. Thus, the high rate of NPF has no impact for the depositors. Furthermore, despite having a high NPF, some banks attempt to collecting funding through sweeteners programs such as prizes or product champion (hajj savings).

Beside those significant variables, the external variables are insignificant, such as inflation rate and BI rate. They do not significantly influence the level of deposit because of a number of factors. First, in monetary transmission theory, the BI rate variable is expected to affect the distribution of financing which in turn will affect investment consumption (gross domestic product) thus keeping the inflation rate stable. Nevertheless, the results indicate that the two variables have no significant effect which is possible because of Islamic banking market share is minor compared to that of the conventional banking i.e. $4.7 \%$. Hence, the differences in those two variables have no effect on the depositors to place their funds in Islamic banks. Second, the awareness of Islamic bank customers to comply with sharia rules and avoid riba. Furthermore, the diversification in financial instruments as alternatives is another factor that is not significant to BI rate and Islamic bank deposit level such as sukuk (Novianto and Hadiwidjojo, 2013).

\section{Conclusion}

During the period of 2011-2015, Islamic banking experienced positive growth although the share asset was still low. Islamic banks has the ability to raise funds with the average ratio of deposit level of $68.70 \%-79.91 \%$ and it channeled into the financing sector with an average financing deposit ratio of $87.12 \%$ $121.87 \%$. This financing deposit ratio are in compliance with the provisions regulated by OJK.

The stability in banking industry is one of the objectives when LPS was founded. The information on the variables that are related to deposit level will help LPS to: First, establish a surveillance system based on sharia bank asset group, capital structure, and financing distribution, in order to anticipate the risk of failure and calculate the adequacy of insurance claim of Islamic bank. This system also will monitor the capital structure and NPF structure, which are influenced by the shrinking capability of banks in collecting funds. Second, develop an effective policy for the implementation of Islamic guarantee scheme so it will have no sudden impact to banks' ability in collecting funds due to the shifting from bank 
products that are not insured based on de principles. Third, applying risk-based premiums is expected to be a disincentive for banks that not implement prudential banking.

\section{References}

Al Arif, M.N.R. (2015). Keterkaitan Kebijakan Pemisahan Terhadap Tingkat Efisiensi Pada Industri Perbankan Syariah di Indonesia. Jurnal Keuangan dan Perbankan, Vol. 19 (2): 295-304.

Alamsyah, H. (2012). Perkembangan dan Prospek Perbankan Syariah Indonesia: Tantangan dalam Menyongsong MEA 2015 [sambutan]. Bank Indonesia.

Anginer A. et.al. (2014). How Does Deposit Insurance Affect Bank Risk? Evidence from The Recent Crisis. Journal of Banking and Finance, 48: 312-321.

Arshad, M.K. (2011). Implementation of an Islamic Deposit Insurance System for The Islamic Financial Service Industry. Fourth Islamic Financial Stability Forum: Strengthening Financial Safety Nets in The Islamic Financial Service Industry. Kuala Lumpur.

Budisantoso, T \& Nuritomo. (2014). Bank dan Lembaga Keuangan Lain (3rd Ed). Jakarta: Salemba Empat.

CIBEST IPB (Center for Islamic Business and Economic Studies Institut Pertanian Bogor). (2014). Pengembangan Skim Penjaminan Simpanan Industri Perbankan Syariah. Jakarta: Lembaga Penjamin Simpanan.

Chernykh, L. \& R.A. Cole. (2011). Does Deposit Insurance Improve Financial Intermediation? Evidence form Russian Experiment. Journal of Banking and Finance. 35 (2): 388-402.

Fahmi I. (2012). Dinamika Struktur Pasar dan Perilaku Bank Serta Dampaknya Terhadap Kinerja Industri Perbankan Syariah. (Unpublished Dissertation). Bogor: Institut Pertanian Bogor.

Ho, T.S. \& A. Saunders. (1981). The Determinants of Bank Interest Margin: Theory and Empirical Evidence. Journal of Financial and Quantitative Analysis 16: $581-600$

Karim AA. (2006). Bank Islam: Analisis fiqih dan keuangan. Jakarta: PT Raja Grafindo Persada.

King R.G. \& R. Levine. (1993). Finance and growth: Schumpeter might be right. The Quarterly Journal of Economics. 108 (3): 717-737.

Kunt A.D. \& E.J. Kane. (2002). Deposit insurance around the globe: Where does it work?. Journal of Economic Perspectives. 16 (2):175-195. 
Lusian, S. et.al. (2015). Analisis Faktor-faktor Penyebab Pembiayaan Bermasalah di Bank Pembiayaan Rakyat Syariah CYZ periode 2009 - 2013. Finance and Banking Journal. 16 (1): 17-37.

Muhamad. (2012). Dasar-Dasar Keuangan Syariah. Yogyakarta: Ekonisia.

Muhammad, D.W. \& A.Y. Lestari. (2015). Konsep Pengaturan Penjaminan Simpanan Nasabah Pada Bank Syariah. Jurnal Media Hukum. 22 (2): 274-293.

Nasution, M.Y. (2012). Dampak Sistem Penjaminan Simpanan Terhadap Tingkat Deposit dan risk-taking Bank Umum di Indonesia Menggunakan Panel Data Analysis: Studi Empiris Periode 1995-2010. (Unpublished Thesis). Jakarta: Universitas Indonesia.

Novianto, A.S. \& D. Hadiwidjojo. (2013). Analisis Faktor-faktor yang Mempengaruhi Penghimpunan Deposito Mudharabah Perbankan Syariah di Indonesia. Jurnal Aplikasi Manajemen. 11 (4): 595-604.

Nuryantono, N. et.al. (2016). Kaitan Kondisi Makroekonomi Dengan NonPerforming Financing Berdasarkan Sektor Ekonomi pada Perbankan Syariah di Indonesia. Jurnal Keuangan dan Perbankan. 20 (1): 104-115.

OJK. (2015). Tinjauan Kebijakan OJK dalam Pengembangan Sektor Ekonomi Prioritas: Analisis Potensi dan Risiko Perbankan. Jakarta: Departemen Pengembangan Pengawasan dan Manajemen Krisis.

Rokhim, R. \& N. Wulandary. (2013). Pengaruh Penjaminan Simpanan, CAR, dan NPL Pada Tingkat Deposit, Risiko Moral Hazard, dan NIM. Jurnal Ekonomi dan Keuangan. 17 (4): 468-485.

Siringoringo, R. (2012). Karakteristik dan Fungsi Intermediasi Perbankan di Indonesia. Buletin Ekonomi Moneter dan Perbankan. 15 (1): 61-83.

Solihin. (2015). Analisis Kesiapan Perbankan Syariah Negara-negara ASEAN dalam Menghadapi Penerapan Masyarakat Ekonomi ASEAN Tahun 2015. (Unpublished Thesis). Bogor: Institut Pertanian Bogor.

Tsuru, K. (2003). Depositors' Selection of Banks and The Deposit Insurance System in Japan: Empirical Evidence and Its Policy Implications. Discussion Paper Series 03: E-024. Research Institute of Economy, Trade and Industry.

Vale, B. (2011). Effects of Higher Equity Ratio on a Bank's Total Funding Costs and Lending. Oslo: Norges Bank.

Widigdo, et.al. (2016). Business process reengineering of funding on Indonesia's Islamic bank. Al-Iqtishad: Jurnal Ilmu Ekonomi Syariah (Journal of Islamic Economics). 8 (1): 19-32. 
Wiranatakusuma, D. \& J. Duasa. (2017). Building an early warning towards the resilience of Islamic banking in Indonesia. Al-iqtishad: Jurnal Ilmu Ekonomi Syariah (Journal of Islamic Economics). 9 (1): 13-32. 